\title{
Neuronal differentiation of PC12 cells induced by engrailed homeodomain is DNA-binding specific and independent of MAP kinases
}

\author{
José-Miguel Cosgaya, Ana Aranda, Jesús Cruces and Enrique Martín-Blanco* \\ Instituto de Investigaciones Biomédicas, CSIC, Departamento de Bioquímica y Biofísica, Facultad de Medicina, Universidad \\ Autónoma de Madrid, Arturo Duperier 4, 28029 Madrid, Spain \\ *Author for correspondence at present address: Department of Zoology, University of Cambridge, Downing St, Cambridge CB2 3EJ, UK \\ (e-mail: em10008@cus.cam.ac.uk) \\ Accepted 3 June; published on WWW 30 July 1998
}

\section{SUMMARY}

Neuronal differentiation may be induced by different mechanisms. In PC12 cells, differentiation can be achieved after stimulation by nerve growth factor through the sustained activation and nuclear translocation of MAPKs. A peptide covering the homeodomain of Drosophila Antennapedia translocates through the cell membrane in primary neurons in culture and reaches their nuclei. This process accelerates neurite elongation. We have examined whether the capacity for neuronal induction is a general characteristic of homeodomains, and whether differentiation proceeds through the same pathway as that induced by growth factors or represents a distinct cellular response. We show here that Engrailed homeodomain is internalized by UR61 cells, a PC12 cell derivative, and that it promotes and sustains neurite outgrowth. This event appears to proceed independently of MAPKs activation, suggesting that either parallel signal transduction pathways are under the control of homeoproteins or that they act downstream of MAPKs. The Fushi tarazu homeodomain also causes neurite outgrowth in UR61 cells and the neurotrophic activities of Engrailed and Fushi tarazu homeodomains correlate with their DNA binding specificities. However, neurite outgrowth is not promoted by Bicoid homeodomain, which recognizes a different DNA sequence. Therefore, the neurotrophic activity of the homeodomains depends not only on DNA-binding ability but also on the specificity of this binding.

Key words: Engrailed, Homeodomain, PC12, MAPK, Differentiation

\section{INTRODUCTION}

The expression of homeobox-containing genes in different regions of the nervous system of vertebrates and invertebrates appear to suggest a role for homeoproteins in neuronal specification or differentiation. In particular, homeoproteins are expressed in overlapping domains along the anteriorposterior axis of the developing hindbrain and spinal cord of vertebrates (Keynes and Krumlauf, 1994). Interestingly, this expression is not restricted to the early periods of development but it is also observed at later stages, during neuronal differentiation.

Much of the functional specificity of homeoproteins, in their ability to regulate specific genes and to assign specific identities, appears to map within their homeodomains. The homeodomain, which has been highly conserved throughout evolution, is comprised of a sequence of 60 amino acids and binds specific DNA sequences (Gehring, 1992). The specificity of DNA-binding of the homeodomain proteins is affected by subtle changes in the homeodomain amino acid composition, that alter their relative affinities for different DNA target sequences (Ades and Sauer, 1994).

A homeodomain peptide of the Drosophila Antennapedia homeoprotein, pAntp, is capable of crossing the plasma membrane of nerve cells in culture. Moreover, its uptake provokes a dramatic morphological differentiation of neuronal cultures (Joliot et al., 1991). pAntp is able to enhance growth of chicken spinal motoneurons and its neurite promoting effect is primarily limited to axons (Bloch-Gallego et al., 1993). This neurotrophic activity is dependent on specific residues which affect its uptake, nuclear localization and DNA binding (Leroux et al., 1993).

PC12 are cells derived from a pheochromocytoma of neuroendocrine origin (Greene and Tischler, 1976). In response to NGF or FGF, PC12 cells undergo partial growth arrest, and differentiate to a phenotype with characteristics of that of sympathetic neurons (Johnson and Vaillancourt, 1994). This effect is mediated by a signal transduction pathway that involves a sustained elevation of p $21^{\text {ras }}$ activity and MAPK phosphorylation. Prolonged MAPK activity and translocation to the nuclei seems to be required for their differentiation to a neuronal fate (Traverse et al., 1994).

In this work we have found that Drosophila engrailed homeodomain (enHD) and fushi tarazu homeodomain (ftzHD) peptides are able to induce neuronal differentiation of UR61 cells, a PC12 derivative, whereas bicoid homeodomain (bcdHD) does not affect neurite extension. We have shown that PC12 derived cells are able to internalize homeodomain 
peptides. We also found that homeodomains affect distinct differentiation pathways, and that these effects depend on the DNA-binding specificity of the peptides. Finally, we observed that neurite outgrowth promoted by Engrailed homeodomain proceeds independently of MAPK activation.

\section{MATERIALS AND METHODS}

\section{PC12 and UR61 cultures}

PC12 cells and the PC12-derived transfectant line UR61 were cultured in RPMI medium containing $10 \%$ donor horse serum (Quality Biological Inc.) and 5\% fetal calf serum (GIBCO). UR61 cells, which were a gift from A. Pellicer, were derived from PC12 cells following transfection with a plasmid containing the transformant mouse $\mathrm{N}$-ras oncogene under the transcriptional control of the dexamethasone-inducible mouse mammary tumor virus (MMTV) promoter (Guerrero et al., 1988). The PC12 subclones were incubated in low-serum conditions (medium containing $0.5 \%$ of a $2: 1$ mixture of donor horse serum:fetal calf serum) with $7 \mathrm{~S}$ NGF and dexamethasone (Dx) at the concentrations and for the times indicated in the figures.

\section{Morphological quantification}

Cell morphology was assessed by phase-contrast microscopy with an inverted microscope and pictures were taken with a Nikon-F2 camera at a magnification of $\times 200$. For morphology studies the cells were seeded at an inital density of 10,000 cells/well using 24-well multidishes and treated with the different factors as indicated in the corresponding figures. The number of differentiated cells (cells bearing neurites with length of more than two cell bodies) and the length and branching of the neurites were determined by analysis in two independent cultures of at least three different fields with about 100 cells/field.

\section{Peptide internalization and intracellular distribution}

enHD and bcdHD internalization were performed as previously described (Bloch-Gallego et al., 1993). $10^{5}$ UR61 cells were resuspended in $500 \mu \mathrm{l}$ of medium and incubated at $37^{\circ} \mathrm{C}$ with $1 \mu \mathrm{g}$ of enHD or bcdHD in the presence or not of $50 \mathrm{ng} / \mathrm{ml}$ NGF or $5 \mathrm{nM}$ Dx. Every 15 minutes, the cells were agitated in order to avoid aggregation. After 2 hours of incubation, cells were washed three times with medium, trypsinized for 15 minutes at $37^{\circ} \mathrm{C}$ in order to eliminate the remaining homeodomains and washed three additional times.

Cells were lysed for 15 minutes at $4{ }^{\circ} \mathrm{C}$ in PBS containing $0.5 \%$ NP40 and the protease inhibitors leupeptin $(20 \mu \mathrm{g} / \mathrm{ml})$, PMSF $(2 \mathrm{mM})$ and $\alpha 2$-macroglobulin $(1 \mu \mathrm{g} / \mathrm{ml})$. The nuclear and cytoplasmic fractions were separated by centrifugation $(2,000 \mathrm{~g}, 15$ minutes at $4^{\circ} \mathrm{C}$ ). Nuclei were solubilized in $800 \mathrm{mM} \mathrm{NaCl}, 1 \mathrm{mM}$ DTT, and both fractions were analyzed by SDS-polyacrylamide gel electrophoresis, and transferred to nylon filters. The presence of enHD and bcdHD in the different fractions was determined by western blot with specific anti-en and anti-bcd antibodies.

\section{Construction of recombinant expression plasmids}

The engrailed homeodomain construct clone (pARenH) was produced from the plasmid pMNRIST. This plasmid contains DNA from the EcoRI site and Met, introduced by site-directed mutagenesis before the Asn at position 453, with a Stop codon after the serine at position 512, to the EcoRI site at nucleotide 1,710 of the clone C2.1 (Poole et al., 1985; Patel et al., 1989). PMNRIST was mutagenized introducing an in-frame NdeI site (CAT ATG) at the position of the Met (ATG). The new NdeI fragment, from this new restriction site, to nucleotide 1,938 was cloned into the NdeI cloning site of the PAR3038 T7 expression vector (Rosenberg et al., 1987) to generate pARenH and to engineer the production of a protein that includes the 60 amino acids of the engrailed homeodomain.

fushi tarazu and bicoid homeodomain constructs (pARftzH, pARbcdH) were engineered by PCR mutagenesis of their respective cDNA clones. The mutagenesis were performed by amplification between two primers at both ends of the homeodomains. At the amino-terminal end we introduced an in-frame NdeI site, and at the carboxy-terminal end an in-frame Stop codon and a BamHI site. Double digest amplified bands were introduced by directional cloning into a double digested NdeI/BamHI PAR3040 T7 expression vector. These plasmids yielded the production of proteins that include the 60 amino acids of the fushi tarazu and bicoid homeodomains.

\section{Protein purification}

One litre cultures from fresh transformation plates were induced by adding IPTG $(1 \mathrm{mM})$ to a mid-log culture at $\mathrm{OD}_{600} 0.7$, and expression proceeded for 2 hours. Harvested cells were frozen in dry ice for at least 30 minutes and thawed in ice. $2 \mathrm{ml}$ of HKEDN buffer (Hepes $25 \mathrm{mM}$, pH 7.6, KCl $0.1 \mathrm{M}$, EDTA $0.1 \mathrm{mM}$, DTT $0.5 \mathrm{mM}$, NP40 $0.1 \%$, leupeptin $10 \mu \mathrm{g} / \mathrm{ml}$, benzamidin $0.1 \mathrm{mM}$, pepstatin A 10 $\mu \mathrm{g} / \mathrm{ml}$, PMSF $1 \mathrm{mM}$, aprotinin $10 \mu \mathrm{g} / \mathrm{ml}$, phenanthroline $1 \mu \mathrm{g} / \mathrm{ml}$ ) were added and aliquots of $1 \mathrm{ml}$ were sonicated in Eppendorf tubes. DNA and bacterial debris were sedimented by high speed centrifugation (TL100 rotor, 68,000 rpm, 45 minutes, $4^{\circ} \mathrm{C}$ ) and the supernatant was frozen in dry ice to further purification. Crude supernatants from 1 litre of cell culture were loaded into phosphocellulose columns equilibrated with HKEDN. The proteins were eluted with linear gradients to HKEDN $\mathrm{KCl} 2 \mathrm{M}$. Homeodomains correspond to $0.8-1.2 \mathrm{M} \mathrm{KCl}$ fractions. Pooled fractions were diluted 20-fold with HKE buffer (Hepes $25 \mathrm{mM}, \mathrm{pH}$ 7.6, $\mathrm{KCl} 50 \mathrm{mM}$, EDTA $0.1 \mathrm{mM}$ ) and loaded into a FPLC Mono S column equilibrated in the same solution. The elution of the retained proteins was carried out with a shallow gradient to $1 \mathrm{M} \mathrm{KCl}$ and monitored at $280 \mathrm{~nm}$. The purified homeodomains eluted at $0.2 \mathrm{M}$ salt.

\section{DNA-binding assays}

The single binding site, GTGGTTAATTGCATGCTAG (SBen), was defined after DNaseI and hydroxyradical footprinting of the $\mathrm{K}$ upstream region of engrailed genomic sequence (data not shown). Reactions for gel mobility shift assays (Fried and Crothers, 1981; Garner and Revzin, 1981) were assembled at $4^{\circ} \mathrm{C}$ for 30 minutes, in a final volume of $10 \mu \mathrm{l}$ and contained $25 \mathrm{mM}$ Hepes, $\mathrm{pH} 7.6,0.1 \mathrm{M}$ $\mathrm{KCl}, 1 \%$ polyvinyl alcohol, $0.1 \% \mathrm{NP}-40,1 \mathrm{mg} / \mathrm{ml}$ bovine serum albumin, and $100 \mathrm{pM}$ DNA-binding-site probe. DNA probes were prepared from purified oligomers by standard $5^{\prime}$ kinasing methods, annealing and purification of double stranded bands from $6 \%$ native polyacrylamide gels. Complexes were resolved on $0.1 \%$ NP40, 7.5 or $6 \%$ (29:1 acrylamide/bis-acrylamide) native acrylamide gels, using a $0.5 \times$ TBE (pH 8.3) buffer. $15 \mathrm{~cm}$ gels were prerun at $4^{\circ} \mathrm{C}$ for 2 hours at 200 volts then run at $4^{\circ} \mathrm{C}$ for $2-3$ hours at the same voltage. Quantitative data were obtained through Phosphorimager analysis.

\section{Determination of MAPK phosphorylation}

UR61 cells were incubated with $10 \mu \mathrm{g}$ enHD/10 $0^{6}$ cells as in the peptide internalization protocol. Cells were treated with $50 \mathrm{ng} / \mathrm{ml}$ NGF or $5 \mathrm{nM}$ Dx in the presence or absence of enHD. After 2 hours, cells were washed three times with medium and seeded in 24-well plates at a density of 20,000 cells/well (time 0 ). At the indicated times, cells were washed twice with $\mathrm{PBS}$ and lysed 10 minutes at $100^{\circ} \mathrm{C}$ in 0.4\% SDS, $0.1 \mathrm{mM} \mathrm{Na} 4 \mathrm{P}_{2} \mathrm{O}_{7}, 0.1 \mathrm{mM} \mathrm{Na}_{3} \mathrm{VO}_{4}, 10 \mathrm{mM} \mathrm{Na}_{2} \mathrm{PO}_{4}, \mathrm{pH}$ 6.7. The samples were analyzed by SDS-polyacrylamide gels and transferred to nylon membranes. p42 and p44 mobility shifts and phosphorylation were detected with anti-Erk and anti-PTyr antibodies, respectively, as described (Qiu and Green, 1992). The percentage of shifted p42 and p44 was quantitated by band densitometry. The data 
are expressed as fold-induction over the corresponding controls at each time.

\section{RESULTS}

\section{Engrailed homeodomain translocates into the nucleus and promotes and sustains neuronal differentiation of UR61 cells}

UR61 cells are a PC12-derived subline in which an N-Ras oncogene with a mouse mammary tumor virus promoter (MMTV) has been stably introduced. Thus, treatment of these cells with dexamethasone transcriptionally activates the N-Ras oncogene. Expression of N-Ras results in a pattern of neuronal differentiation resembling the response of PC12 cells to NGF or FGF (Guerrero et al., 1988). UR61 cells are unable to respond morphologically to NGF, although low (p75) and high affinity (TrkA) receptors for NGF are present (Cosgaya et al., 1997).

Drosophila engrailed gene codes for a 552 amino acid nuclear protein with a homeodomain near its carboxy-terminal end. This homeodomain has been shown to mediate Engrailed binding by interacting with specific bases and phosphate groups through major and minor grooves in the DNA (Kissinger et al., 1990). A 60 amino acid Engrailed homeodomain peptide (enHD) expressed in E. coli was purified to homogeneity (see below). This peptide was used in all subsequent DNA-binding and induction experiments.

To analyze translocation and nuclear localization of enHD, UR61 cells were incubated with the homeodomain for 2 hours. Cells were then washed, and the amount of peptide present within the nuclear fraction was detected with the specific

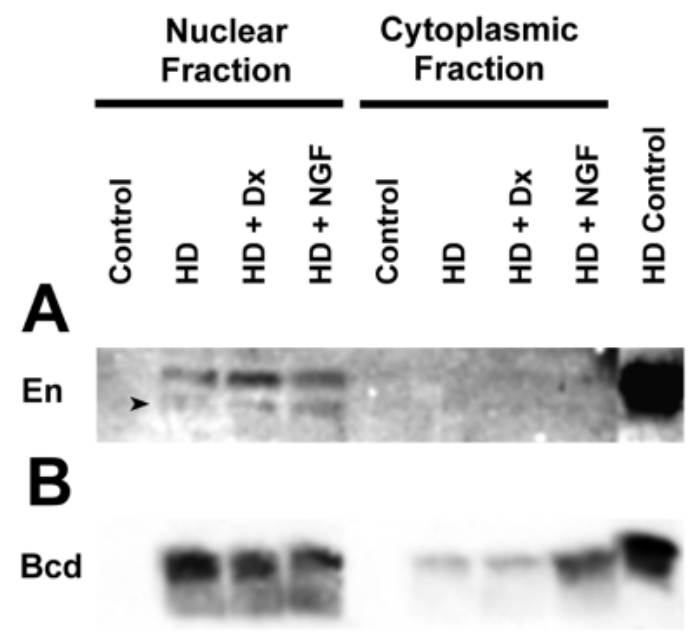

Fig. 1. Internalization of Engrailed and Bicoid homeodomains by UR61 cells. Purified homeodomains $\left(10 \mu \mathrm{g} / 10^{6}\right.$ cells $)$ were incubated for 2 hours with UR61 cells alone or in the presence of $5 \mathrm{nM}$ dexamethasone or $50 \mathrm{ng} / \mathrm{ml}$ NGF. Cytoplasmic and nuclear fractions were prepared for analysis by PAGE. (A) enHD was detected by antien immunoblotting as described in Materials and methods. Nuclear internalization of the enHD was independent of the presence of dexamethasone or NGF. The arrowhead indicates the presence of a band corresponding to a degradation product. (B) bcdHD was detected by anti-bcd inmunoblotting. Dx or NGF do not affect bcdHD internalization. monoclonal antibody 4D9 (Patel et al., 1989). Fig. 1A shows that enHD was efficiently translocated through the cell membranes and accumulates in the nuclear fraction. This translocation was unaffected by the presence of dexamethasone or NGF.

The purified enHD peptide was added to UR61 cultures for different lengths of time. Ten days of incubation in the presence of the homeodomain rendered flat polygonal cells emitting small spikes $(18.3 \%$ cells versus $8.0 \%$ in controls) (compare Fig. 2A and B), a phenotype corresponding to early stages of neurite outgrowth. This effect was potentiated by the presence of either NGF or suboptimal amounts of dexamethasone (5 $\mathrm{nM})$. Under conditions in which neither NGF, nor dexamethasone alone promoted a neurotrophic effect $(8 \%$ and $7.1 \%$ of flat polygonal cells) (Fig. 2C and E), the combination with enHD induced cell flattening, spikes and neuronal differentiation with emission of neurites $(23.4 \%$ and $35.2 \%$, respectively) (Fig. 2D and F; more dramatic effects are seen for ftzHD, see below and also Fig. 6). These results suggest that the internalization of enHD, in some way, cooperates with p $21^{\text {ras }}$ activation to promote neuritogenesis. Furthermore, enHD was able to sustain neurite growth after decay of p21 ras expression. Neuronal differentiation mediated by optimal concentrations of dexamethasone in UR61 cells reached a peak at between 3 and 5 days of induction. At later stages, UR61 cells started to dedifferentiate and the emitted neurites collapse gradually (Fig. 3A,C,E). However, when enHD was present, neuronal differentiation was sustained longer (Fig. 3B,D,F). After 8 and 10 days in the presence of the enHD, $50 \%$ and $17 \%$
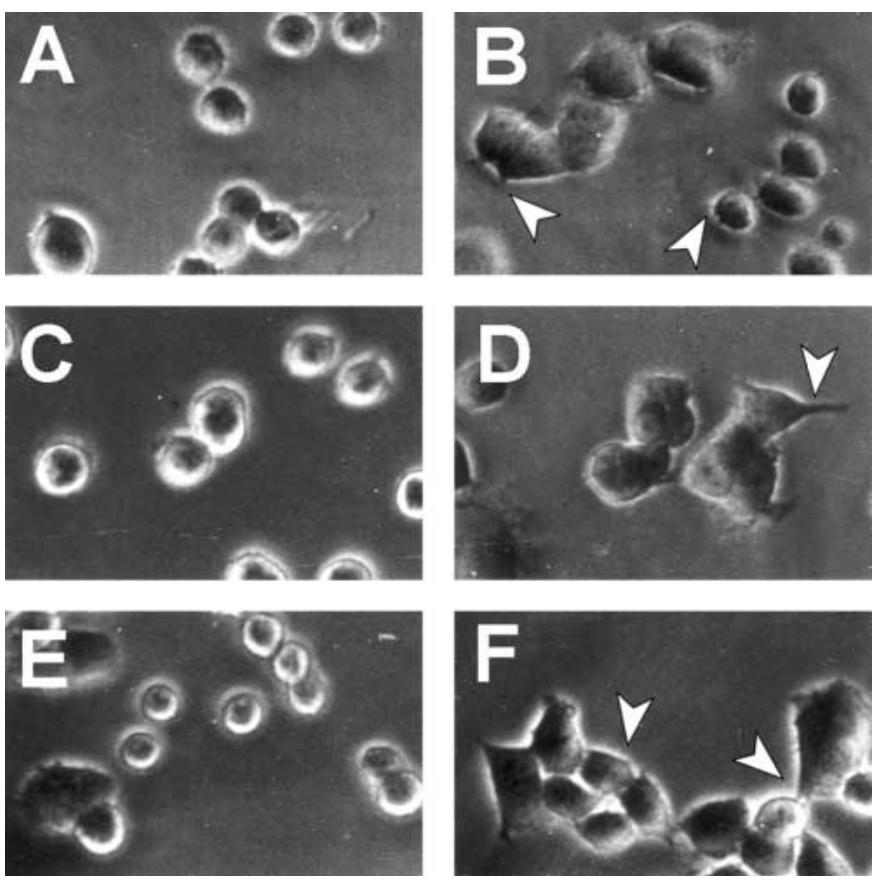

Fig. 2. Engrailed homeodomain induces neuronal differentiation of UR61 cells. Long treatment of UR61 cells (10 days) with $1 \mu \mathrm{g} / \mathrm{ml}$ enHD (B) promotes morphological changes characteristic of neuronal differentiation (arrowheads point to cell flattening and spikes and short neurites) in comparison with control cells (A). enHD is also able to induce neurite outgrowth after 7 days in the presence of $50 \mathrm{ng} / \mathrm{ml} \mathrm{NGF,} \mathrm{compare} \mathrm{D} \mathrm{and} \mathrm{C,} \mathrm{or} 5$ days with low doses of dexamethasone $(5 \mathrm{nM})$, compare $\mathrm{F}$ and $\mathrm{E}$. 

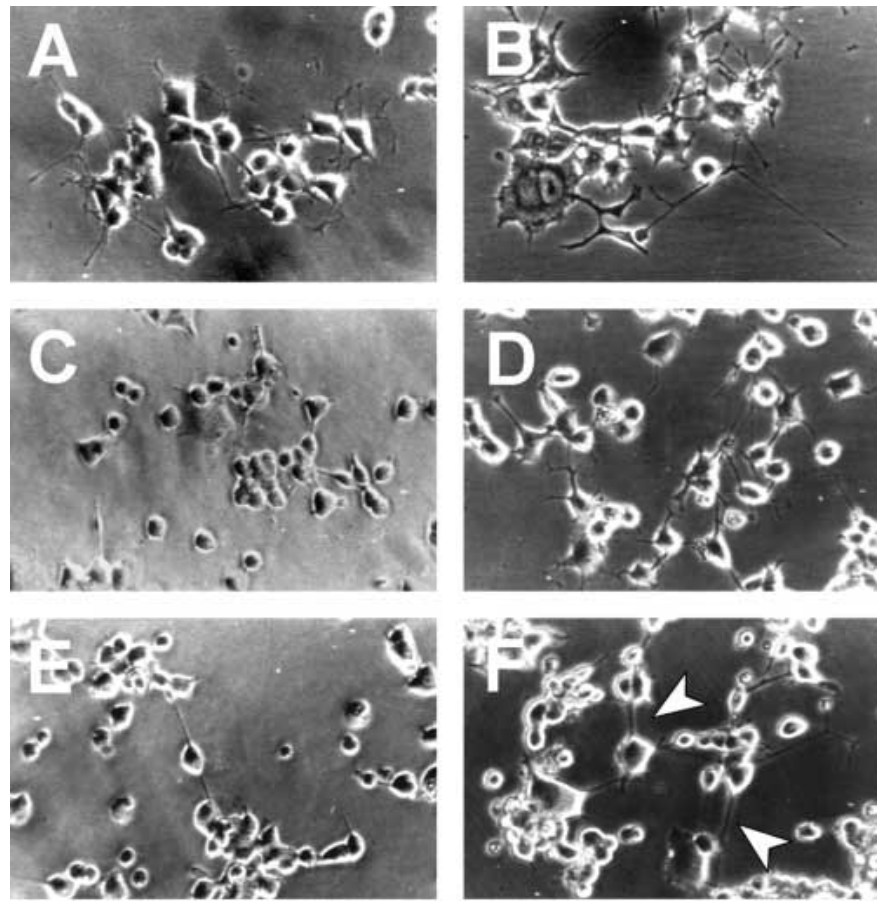

G

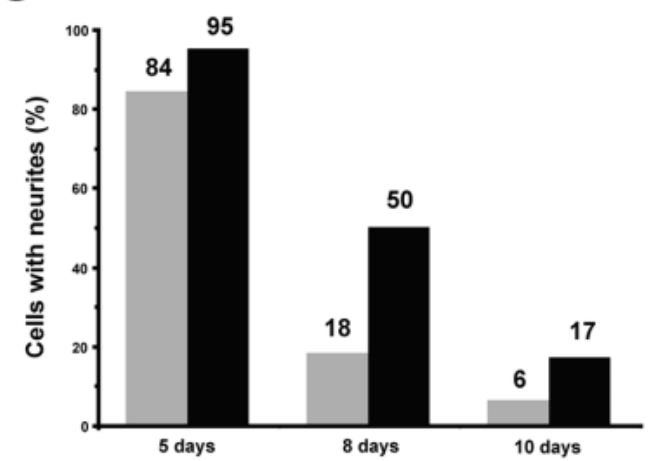

Fig. 3. Engrailed homeodomain sustains neuronal differentiation of UR61 cells induced by dexamethasone. UR61 cells treated with a high concentration of dexamethasone $(100 \mathrm{nM})$ were mantained for different times in the absence $(A, C, E)$ or presence $(B, D, E)$ of high concentrations of enHD $(1 \mu \mathrm{g} / \mathrm{ml})$. Neuronal differentiation is induced by dexamethasone in UR61 cells after 2-4 days of incubation (A,B). Posteriorly, cells return to an undifferentiated state after $7(\mathrm{C})$ or 10 days (E). In the presence of enHD, however, the neuronal-differentiated state is preserved up to 10 days after plating (D and F, arrowheads). The quantitation of these results, expressed as the percentage of cells bearing neurites of a length of more than two cell bodies, is presented in G (- enHD, grey bars; + enHD, black bars).

of the cells have neurites with lengths of at least 2 cell bodies compared with $18 \%$ and $6 \%$ in controls (Fig. 3G).

\section{Engrailed homeodomain neurotrophic activity is independent of the activation of MAPKs}

In PC12 cells, the neurotrophic factors NGF and FGF induce a sustained phosphorylation of p42 and p44 MAPKs. Phosphorylation turnover was not detectable for at least 6 hours following the addition of the growth factors, and neuronal differentiation appears to be associated with this prolonged MAPK activation (Traverse et al., 1994).

Phosphotyrosine immunoblotting of proteins from dexamethasone-treated UR61 cells revealed a stimulation of protein tyrosine phosphorylation of species with mobilities corresponding to 42 and $44 \mathrm{kDa}$ (data not shown). These appear to be, respectively, p42 and p44 MAPKs based on immunoprecipitation with anti-MAPKs antiserum (Qiu and Green, 1992). We treated UR61 cells with $5 \mathrm{nM}$ dexamethasone or $50 \mathrm{ng} / \mathrm{ml} \mathrm{NGF}$ in the absence or the presence of enHD (Fig. 4A (p44) and B (p42)). Very similar effects were observed for both species. Dexamethasone induced a MAPK mobility shift after 8 hours of treatment which returned to normal levels after 48 hours, whereas NGF induced a shift at 1 hour of treatment, also returning to basal levels at 48 hours. enHD alone did not cause MAPK activation. In addition, the homeodomain did not modify (enhance or supress) the MAPKs mobility shifts observed with dexamethasone or NGF. Therefore, enHD does not seem to interfere with the level of activation of the $\mathrm{p} 21^{\text {ras }}$ pathway, under conditions in which the peptide dramatically alters the differentiation of UR61 cells. Similar results were also obtained at other times of incubation (data not shown).

\section{Neurite growth-promoting activity is linked to DNA- binding specificity}

The DNA-binding of homeoproteins is mediated by their homeodomains. However, divergent homeoproteins including Engrailed and Fushi tarazu can recognize similar DNA sequences. On the other hand, Bicoid has been shown to bind to different sequences, and this differential binding seems to be mediated by specific amino acids in its homeodomain (Gehring, 1992).

The mobility of the purified homoeodomains peptides in SDS-polyacrylamide gel electrophoresis is shown in Fig. 5A. We have examined DNA binding of these homeodomains. Firstly, we found that bcdHD, enHD and ftzHD (Fig. 5B) were able to bind DNA in the absence of any extra homeoprotein sequences. We performed gel shift assays with a constant concentration of DNA (SBen) and with increasing concentrations of Engrailed, Fushi tarazu and Bicoid purified homeodomains. The saturation plots shown in Fig. 5C give a measure of the relative affinities of these different homeodomains for the octamer-related sequence that we used. The affinity of enHD or ftzHD for this sequence $\left(K_{\mathrm{d}}=1 \times 10^{-9}\right.$ $\mathrm{M})$ is in the same order of magnitude as that found in bacterial or yeast operator-repressor systems. However, bcdHD has a 100 -fold lower affinity $\left(K_{\mathrm{d}}=1 \times 10^{-7} \mathrm{M}\right)$, probably due to its different recognition helix (Hayashi and Scott, 1990).

We tested, whether bcdHD or ftzHD were able to induce a neurotrophic response in UR61 cells similar to that caused by enHD. Importantly, neuronal differentiation seems to depend on DNA-binding specificity. ftzHD had no evident neurotrophic activity by itself (compare Fig. 6A and C) but dramatically enhanced the effects of dexamethasone (compare Fig. 6D and F) and NGF (compare Fig. 6G and I). On the contrary, bcdHD, which binds different DNA sequences, did not affect UR61 morphology under any condition (Fig. 6B,E,H).

Fig. 1B shows that bcdHD was efficiently translocated through the cell membranes and accumulates in the nuclear 

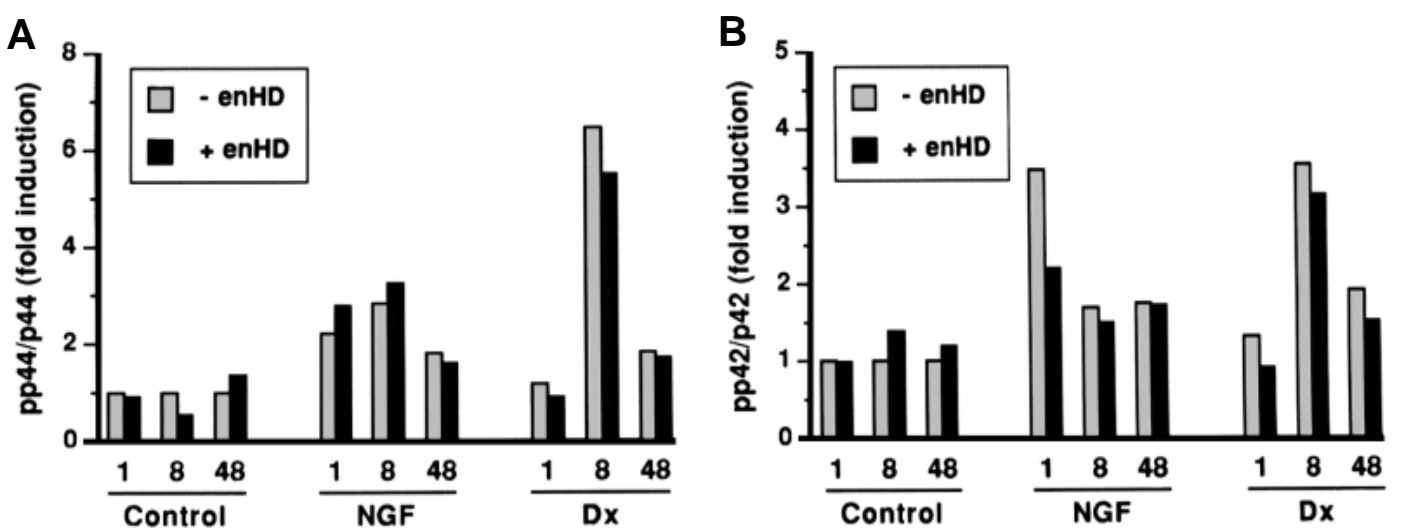

Fig. 4. Temporal patterns of induced MAPK phosphorylation. UR61 cells were treated with $5 \mathrm{nM}$ dexamethasone or $50 \mathrm{ng} / \mathrm{ml} \mathrm{NGF}$ in the absence or the presence of $10 \mu \mathrm{g} / \mathrm{ml}$ enHD for 1,8 and 48 hours. Control cells did not receive any treatment. MAPKs were detected by antiMAPK immunoblotting as described in Materials and Methods. The proportions of phosphorylated p42 (A) and p44 (B) were quantified by scan densitometry. All the data are referred to the control value for each time. The presence of the enHD does not induce a p42 and/or p44 mobility shift and does not affect the responses to dexamethasone or NGF.

fraction. The presence of dexamethasone or NGF does not affect bcdHD translocation.

\section{Engrailed homeodomain affects PC12 cell differentiation}

The role of homeodomain peptides promoting neuronal differentiation is not restricted to UR61 cells. PC12 parental cells undergo differentiation towards a neuronal pathway when they are treated with nanomolar concentrations of NGF or FGF. They become flat and polygonal and emit small spikes and neurites that can reach several cell bodies at late stages. PC12 cells can also differentiate to chromaffin cells after stimulation with glucocorticoids.

We tested whether enHD was able to promote differentiation of PC12 cells in culture. At the highest concentration that we used $(10 \mu \mathrm{g} / \mathrm{ml})$, we were unable to detect any difference between enHD-treated cells and controls (Fig. 7B). Nevertheless, enHD enhanced the neurotrophic efect of NGF. After 24 hours of treatment with a suboptimal NGF concentration $(1 \mathrm{ng} / \mathrm{ml})$, only a small percentage of the cells (less than 5\%) start to differentiate, acquiring characteristics of the earlier stages of neuronal differentiation, cell flattening and increase in body size with emission of spikes and short neurites that usually are between 1 and 3 cell bodies in length. The addition of enHD increases both the number of cells with this morphology (threefold increase; Fig. 1A, left panel) and the extent of differentiation (data not shown).

In the presence of higher NGF concentrations $(50 \mathrm{ng} / \mathrm{ml})$, enHD did not change significatively the number of cells bearing neurites, but accelerated cell differentiation (Fig. 7A, right
A

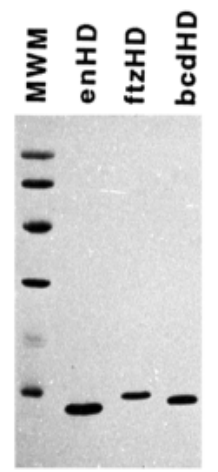

B

$\begin{array}{lllllllll}1 & 2 & 3 & 4 & 5 & 6 & 7 & 8 & 9\end{array}$

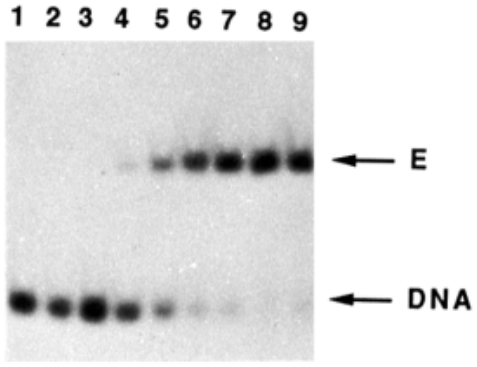

C

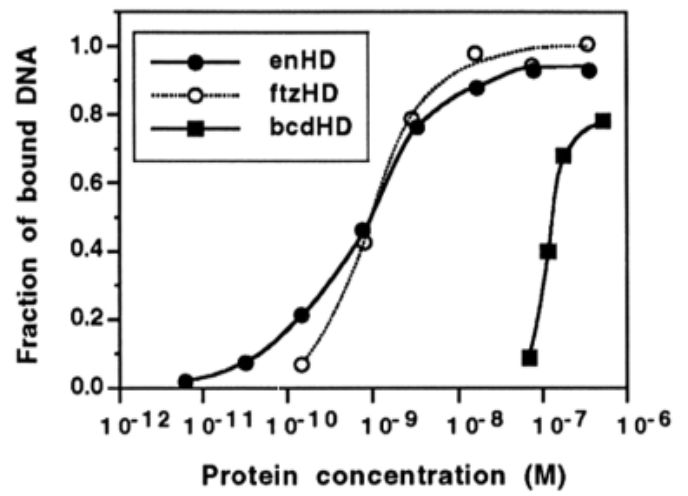

Fig. 5. Protein purification and DNA binding of Engrailed, Fushi tarazu and Bicoid homeodomains. (A) Coomassie staining of a PAGE (10$16 \%$ gradient) of the purified Engrailed, Fushi tarazu and Bicoid homeodomains. Induction and purification were performed as indicated in Materials and Methods. Each protein has only 61 amino acids, including the starting methionine. The different mobility of the different homeodomains is due to the different amino acid composition. (B) enHD binds to a SBen single binding site probe. 100 pM DNA were incubated with increasing concentrations of purified enHD and the binding determined by gel mobility shift assay. (C) Titration curves for a gel mobility shift experiment for Engrailed (1), Fushi tarazu (m) and Bicoid (n) homeodomains binding to SBen. DNA-binding reactions were assembled and complexes were resolved as described in Materials and Methods. Estimated $K_{\mathrm{d}}$ values are: Engrailed, $2 \times 10^{-9} \mathrm{M} ;$ Fushi tarazu, $2 \times 10^{-9} \mathrm{M}$; Bicoid, $1 \times 10^{-7} \mathrm{M}$. 
Fig. 6. Fushi tarazu

homeodomain, but not Bicoid homeodomain, promotes neuronal differentiation of UR61 cells. UR61 cells were plated at low density and incubated alone $(\mathrm{A}, \mathrm{D}, \mathrm{G})$ with Bicoid $(1 \mu \mathrm{g} / \mathrm{ml})(\mathrm{B}, \mathrm{E}, \mathrm{H})$ or Fushi tarazu $(1 \mu \mathrm{g} / \mathrm{ml})(\mathrm{C}, \mathrm{F}, \mathrm{I})$ homeodomains with no further treatment for 24 hours $(\mathrm{A}, \mathrm{B}, \mathrm{C})$, or in the presence of a low concentration of

dexamethasone (5 nM) (D,E,F) for 24 hours or a high concentration of NGF (50 $\mathrm{ng} / \mathrm{ml})(\mathrm{G}, \mathrm{H}, \mathrm{I})$ for 10 days. Bicoid was unable to promote any effect in any condition. Fushi tarazu, however, induced neuronal differentiation even in the absence of any other cofactor (C). Arrowheads point to neurites of a length of several cell bodies.
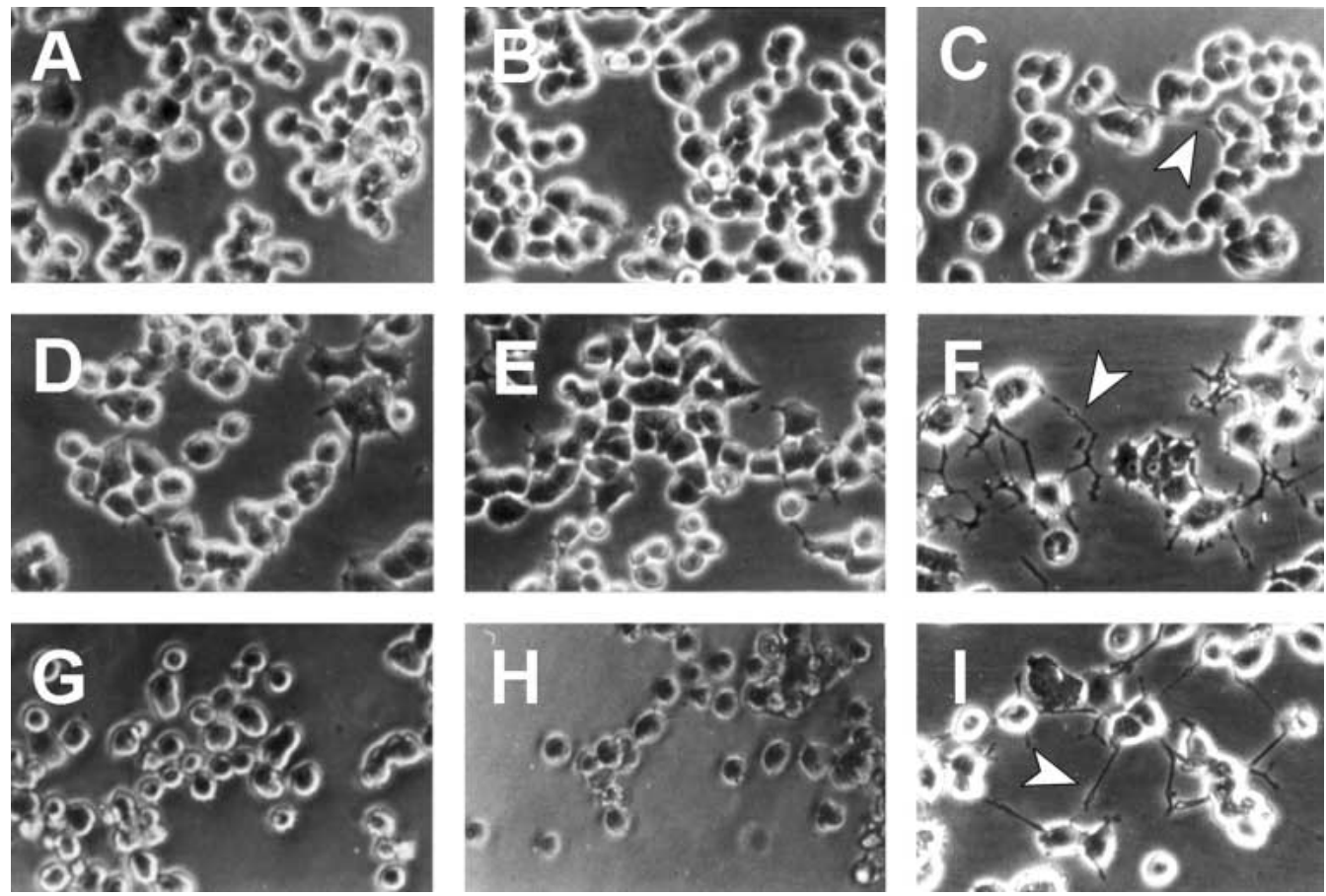

Fig. 7. Engrailed homeodomain enhances neuronal differentiation of PC12 cells induced by nerve growth factor. PC12 cells were plated at low density in low serum conditions. (A) The cells were incubated with $1 \mathrm{ng} / \mathrm{ml}$ NGF (left panel) or $50 \mathrm{ng} / \mathrm{ml}$ (right panel) in the absence (m) or presence (l) of $1 \mu \mathrm{g} / \mathrm{ml}$ enHD and the number of differentiated cells was counted at the indicated times. (B) Morphology of PC12 cells after 72 hours treatment with $50 \mathrm{ng} / \mathrm{ml} \mathrm{NGF}$ and/or $1 \mu \mathrm{g} / \mathrm{ml}$ enHD. In these conditions enHD enhances the neuronal differentiation promoted by NGF, but does not show any effect alone.

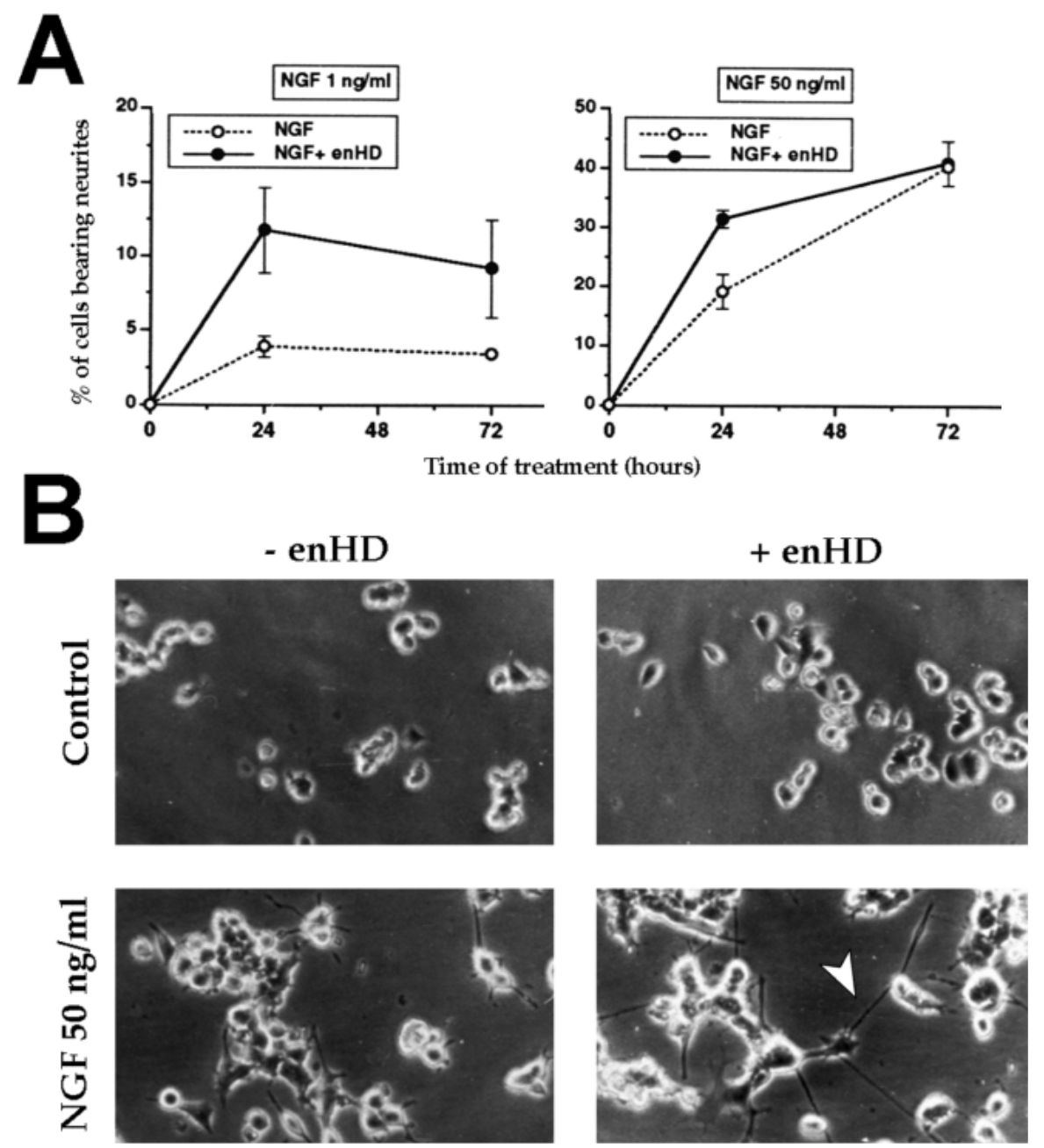


Table 1. enHD potentiates the differentiation of $\mathrm{PC} 12$ cells induced by NGF

\begin{tabular}{lcc}
\hline Parameter & NGF & NGF + enHD \\
\hline $\begin{array}{l}\text { Cells with neurites } \\
\quad \% \text { of total) }\end{array}$ & $24 \%$ & $26 \%$ \\
$\quad$ Neurites/cell & 1.3 & 1.8 \\
$\quad$ Cells with branched neurites & $23 \%$ & $47 \%$ \\
$\quad$ ( $\%$ of differentiated cells) & & \\
Neurite length & 4.4 & 5.9 \\
$\quad$ (cellular bodies) & & \\
Distribution of neurites by length & & \\
$\quad$ (\% of total) & & \\
$\quad 2-4$ cell bodies & $76 \%$ & $45 \%$ \\
$\quad 4-10$ cell bodies & $19 \%$ & $41 \%$ \\
$\quad>10$ cell bodies & $5 \%$ & $14 \%$
\end{tabular}

Cells were treated with $50 \mathrm{ng} / \mathrm{ml}$ NGF for 72 hours in low serum conditions in the presence or absence of $1 \mu \mathrm{g} / \mathrm{ml}$ enHD. The number of cells bearing neurites were determined as indicated in Materials and Methods.

panel). enHD also enhanced the extent of the differentiation induced by NGF (Fig. 7B). The addition of enHD causes an increase in both the number of neurites/cell as well as the length and branching of these processes leading to a more mature differentiation (Table 1). Taking these results together, they show that enHD is able to interfere in the PC12 cell differentiation switch and that it drives the cells towards a neuronal morphology.

\section{DISCUSSION}

\section{Neuronal differentiation: the homeodomain and the MAPK signalling pathway}

Several studies have shown that expression of oncogenic $\mathrm{p} 21^{\text {ras }}$ in PC12 cells causes neuronal differentiation similar to that occurring in NGF or FGF treated cells (Noda et al., 1985; Guerrero et al., 1988). These results imply that $\mathrm{p} 21^{\text {ras }}$ activity alone is sufficient for induction of PC12 cell neuronal differentiation. Yet, EGF also induces p21 ${ }^{\text {ras }}$ activity but does not induce differentiation, implying to the contrary that $\mathrm{p} 21^{\text {ras }}$ is not sufficient. These distinct effects have been explained by differences in the extent and duration of the activation of $\mathrm{p} 42$ and p44 MAPKs.

In the UR61 cells the neurotrophic effects of Engrailed, and presumably Fushi tarazu homeodomains seem to be independent of MAPKs (Fig. 4). Homeodomains could mediate the activation of parallel intracellular signalling pathways partially redundant with those initiated by growth factors. Alternatively, HDs would exert their action by direct competition with endogenous homeoproteins for target sites. This might mimic the effects of MAPKs activation and affect the expression of their downstream targets. We favour this second hypothesis on the grounds of the enhancement promoted by enHD of the neurite outgrowth induced by suboptimal amounts of dexamethasone in UR61 (Fig. 2), as well as the maintenance of the differentiated state reached by UR61 cells at high dexamethasone concentrations (Fig. 3).

This model could explain the cooperative effect on UR61 cells of NGF with enHD, or ftzHD (Figs 2, 6). The morphological response to NGF is markedly impaired in UR61 cells as well as in their parental strain (U7-PC12) (Guerrero et al., 1988), although several 'early response genes' to the factor are not altered (Thompson et al., 1990). This could be due to a mutation, downstream in the pathway, that would impair signalling. In this scenario, this mutation could be partially suppressed by the presence of homeodomains. These acting as competitors would affect the implementation of the pattern of gene expression dictated by $\mathrm{p} 21^{\text {ras }}$.

\section{DNA-binding specificity and neuronal differentiation}

Mutations in homeodomain genes affect many different stages in neuronal development. In developing motor neurons, homeoproteins are detected as the earliest markers after their final mitotic division (Ericson et al., 1992). They are also involved in the control of the final stages of neural differentiation and participate in the patterning of synaptic inputs (Miller et al., 1992).

Regarding the ability of homeodomains to induce a neuronal differentiation pathway in cultured cells, we should take three events into consideration: the uptake of the peptide by the cell, its translocation to the nuclei and its ability to bind DNA and promote a specific response.

It has been shown that pAntp internalization in primary neurons in culture is mediated by polysialic acid (PSA), which is only present in neuronal tissues (Joliot et al., 1994). The interactions between homeodomains and PSA seem to be similar to those described for the homeodomain and DNA (Kissinger et al., 1990). PSA could act as a transmembrane transporter for pAntp, and very likely for other homeodomains. The ability to internalize enHD by UR61 cells (Fig. 1) is probably related to their origin as a neuroadrenal cell line.

DNA binding seems to be absolutely necessary for pAntp neurotrophic effect. Mutant homeodomains with an impaired ability to bind DNA are unable to promote any differentiative effects (Leroux et al., 1993). Moreover, Pantp driven differentiation correlates with the downregulation of target genes for endogenous homeoproteins (Leroux et al., 1995) suggesting that the binding to DNA by the homeodomain is important during the differentiation process. Our data indicate that DNA binding ability is necessary to enhance neuronal differentiation but not sufficient. Bicoid, which has a divergent recognition helix, has an affinity constant one hundred fold lower than that of Engrailed or Fushi tarazu for the same DNA sequence (Fig. 5), although it is able to bind DNA with high affinity, but with different specificity (Hanes and Brent, 1989). The facts that enHD, bcdHD and AntpHD are internalized in neuronal cells, that ftzHD is also probably taken up (as is suggested by its morphological effects) and that the mechanism of internalization is mediated by non-specific interactions to PSA, strongly support the suggestion that Bicoid altered specificity could be responsible for the inability of Bicoid homeodomain to induce neurite outgrowth in UR61 cells (Fig. 6).

The control of differentiation events at the molecular level by regulatory transcription factors depends on their specificity of DNA-binding. The different affinities of the homeodomains for DNA sites will affect the responses in which they could interfere. In this scenario, we could conceive Bicoid playing a role in processes other than neuronal differentiation.

Homeoproteins regulate the initiation rate of transcription of target genes and seem to be involved in the enhancement or repression of homologous or heterologous promoters. These effects are mediated by the binding of the homeoproteins to 
DNA through their homeodomains. We demonstrate here that cell uptake and induction of neuronal differentiation are not effects restricted to Antennapedia homeodomain, and they could be general properties of the homeodomain family. Engrailed, Fushi tarazu and Antennapedia Hds recognize similar target sequences, and all three promote neuronal differentiation. They would compete with endogenous homeoproteins, not just their mammalian homologues, and play a dominant negative role.

The physiological significance of the spontaneous internalization of homeoproteins is not yet clear. Other roles, besides acting as transcription factors, have been described for homeoproteins: e.g. Bicoid as an RNA binding protein controlling the translation of Caudal (Rivera-Pomar et al., 1996). The possibility that homeoproteins are secreted and could have a paracrine function has already been discussed (Prochiantz and Theodore, 1995; Rubartelli and Sitia, 1995). Supporting this view, it has recently been shown that the full length Hoxa-5 homeoprotein is taken up by fibroblasts and neurons in culture (Chatelin et al., 1996). Without supporting or denying the possible role of homeoproteins as polypeptidic messengers, we must point out the non-autonomous effects previously described for engrailed during Drosophila development (Poole and Kornberg, 1988). Furthermore, in relation to our results, we should notice the transport of the homeodomain protein Knotted1 through plasmodesmata in maize (Lucas et al., 1995) and the presence of Emx1 in axons of olfactory sensory neurons along their entire length (Briata et al., 1996).

We thank Tom Kornberg in whose lab this work was initiated and Aviva Tolkovsky for critical reading of the manuscript. The rabbit anti-bcd antibody was kindly provided by Rolando Rivera-Pomar. This work was supported by grants from the DGICYT (PM92-0002 and PB94-0094), by a grant from the Fundación Ramón Areces, and by the Comunidad de Madrid.

\section{REFERENCES}

Ades, S. E. and Sauer, R. T. (1994). Differential DNA-binding specificity of the Engrailed homeodomain: the role of residue 50. Biochemistry 33, $9187-$ 9194.

Bloch-Gallego, E., Leroux, I., Joliot, A. H., Volovitch, M., Henderson, C. E. and Prochiantz, A. (1993). Antennapedia homeobox peptide enhances growth and branching of embryonic chicken motoneurons in vitro. J. Cell Biol. 120, 485-492.

Briata, P., Diblas, E., Gulisano, M., Mallamaci, A., Iannone, R., Boncinelli, E. and Corte, G. (1996). Emx1 homeoprotein is expressed in cell-nuclei of the developing cerebral-cortex and in the axons of the olfactory sensory neurons. Mech. Dev. 57, 169-180.

Cosgaya, J. M., Perona, R. and Aranda, A. (1997). Retinoic acid induces secretion of transforming growth factors by PC12 pheochromocytoma cells. Oncogene 14, 579-587.

Chatelin, L., Volovitch, M., Joliot, A. H., Perez, F and Prochiantz, A. (1996). Transcription factor Hoxa-5 is taken up by cells in culture and conveyed to their nuclei. Mech. Dev. 55, 111-117.

Ericson, J., Thor, S., Edlund, T., Jessell, T. M. and Yamada, T. (1992). Early stages of motor-neuron differentiation revealed by expression of homeobox gene islet-1. Science 256, 1555-1560.

Fried, M. and Crowthers, D. M. (1981). Equilibria and kinetics of lac repressor-operator interactions by polyacrylamide gel electrophoresis. Nucl. Acids Res. 9, 6505-6525.

Garner, M. M. and Revzin, A. (1981). A gel electrophoresis method for quantifying the binding of protein to specific DNA regions: application to components of the Escherichia coli lactose operon regulatory system. Nucl. Acids Res. 9, 3047-3060.

Gehring, W. J. (1992). The homeobox in perspective. Trends Biochem. Sci. 17, 277-280.
Greene, L. A. and Tischler, A. S. (1976). Establishment of a noradrenergic clonal line of rat adrenal pheochromocytoma cells which respond to nerve growth factor. Proc. Nat. Acad. Sci. USA 73, 2424-2428.

Guerrero, I., Pellicer, A. and Burstein, D. E. (1988). Dissociation of c-fos from ODC expression and neuronal differentiation in a PC12 subline stably transfected with an inducible N-ras oncogene. Biochem. Biophys. Res. Commun. 150, 1185-1192.

Hanes, S. D. and Brent, R. (1989). DNA specificity of the Bicoid activator protein is determined by homeodomain recognition helix residue 9. Cell 57, $1275-1283$

Hayashi, S. and Scott, M. P. (1990). What determines the specificity of action of Drosophila homeodomain proteins? Cell 63, 883-894.

Johnson, G. L. and Vaillancourt, R. R. (1994). Sequential protein-kinase reactions controlling cell-growth and differentiation. Curr. Opin. Cell Biol. 6, 230-238.

Joliot, A., Pernelle, C., Deagostini-Bazin, H. and Prochiantz, A. (1991). Antennapedia homeobox peptide regulates neural morphogenesis. Proc. Nat. Acad. Sci. USA 88, 1864-1868.

Joliot, A. H., Triller, A., Volovitch, M., Pernelle, C. and Prochiantz, A. (1994). $\alpha-2-8$-Polysialic acid is the neuronal surface receptor of Antennapedia homeobox peptide. New Biol. 3, 1121-1134.

Keynes, R. and Krumlauf, R. (1994). Hox genes and regionalization of the nervous-system. Annu. Rev. Neurosci. 17, 109-132.

Kissinger, C. R., Liu, B., Martin-Blanco, E., Kornberg, T. B. and Pabo, C. O. (1990). Crystal structure of an Engrailed homeodomain-DNA complex at $2.8 \AA$ resolution: a framework for understanding homeodomain-DNA interactions. Cell 63, 579-590.

Leroux, I., Joliot, A. H., Bloch-Gallego, E., Prochiantz, A. and Volovitch, M. (1993). Neurotrophic activity of the antennapedia homeodomain depends on its specific DNA-binding properties. Proc. Nat. Acad. Sci. USA 90, 9120-9124.

Leroux, I., Duharcourt, S., Volovitch, M., Prochiantz, A. and Ronchi, E. (1995). Promoter-specific regulation of gene-expression by an exogenously added homeodomain that promotes neurite growth. FEBS Lett. 368, 311314

Lucas, W. J., Bouchepillon, S., Jackson, D. P., Nguyen, L., Baker, L., Ding, B. and Hake, S. (1995). Selective trafficking of Knotted 1 homeodomain protein and its messenger-RNA through plasmodesmata. Science 270, 19801983.

Miller, D. M., Shen, M. M., Shamu, C. E., Burglin, T. R., Ruvkun, G., Dubois, M. L., Ghee, M. and Wilson, L. (1992). C-elegans unc-4 gene encodes a homeodomain protein that determines the pattern of synaptic input to specific motor neurons. Nature 355, 841-845.

Noda, M., Ko M., Ogura, A., Liu, D-G., Amano, T., Takano, T. and Ikawa, Y. (1985). Sarcoma viruses carrying ras oncogenes induce differentiationassociated properties in a neuronal cell line. Nature 318, 73-75.

Patel, N. H., Martín-Blanco, E., Coleman, K. G., Poole, S. J., Ellis, M. C., Kornberg, T. B. and Goodman, C. S. (1989). Espression of Engrailed proteins in Arthropods, Annelids, and Chordates. Cell 58, 955-968.

Poole, S. J., Kauvar, L. M., Drees, B. and Kornberg, T. (1985). The engrailed locus of Drosophila: structural analysis of an embryonic transcript. Cell 40, 37-43.

Poole, S. J. and Kornberg, T. B. (1988). Modifying expression of the engrailed gene of Drosophila-melanogaster. Development 104, 85-93.

Prochiantz, A. and Theodore, L. (1995). Nuclear growth factors. BioEssays 17, 39-44.

Qiu, M.-S. and Green, S. H. (1992). PC12 cell neuronal differentiation is associated with prolonged p $21^{\text {ras }}$ activity and consequent prolonged ERK activity. Neuron 9, 705-717.

Rivera-Pomar, R., Niessing, D., Schmidtott, U., Gehring, W. J. and Jackle, H. (1996). RNA-binding and translational suppression by Bicoid. Nature 379, 746-749.

Rosenberg, A. H., Lade, B. N., Chui, D.-S., Lin, S.-W., Dunn, J. J. and Studier, F. W. (1987). Vectors for selective expression of cloned DNAs by T7 RNA polymerase. Gene 56, 125-135.

Rubartelli, A. and Sitia, R. (1995). Entry of exogenous polypeptides into the nucleus of living cells - facts and speculations. Trends Cell Biol. 5, 409-412.

Thompson, T. M., Green, S. H., Trotta, R. J., Burstein, D. E. and Pellicer, A. (1990). Oncogene N-ras mediates selective inhibition of c-fos induction by nerve growth factor and basic fibroblast growth factor in a PC12 cell line Mol. Cell. Biol. 10, 1556-1553.

Traverse, S., Seedorf, K., Paterson, H., Marshall, C. J., Cohen, P. and Ullrich, A. (1994). EGF triggers neuronal differentiation of PC12 cells that overexpress the EGF receptor. Curr. Biol. 4, 694-701. 